\title{
PENGARUH BUDAYA KERJA TERHADAP PRODUKTIVITAS KERJA PADA DISDUKCAPIL KABUPATEN PESISIR BARAT
}

\author{
Yudi Mintaraga ${ }^{(1)}$, Fahrizi $^{(2)}$, Iwan Zulfikar ${ }^{(3)}$ \\ Fakultas Ekonomi Universitas Sang Bumi Ruwa Jurai \\ yudi_mintaraga@gmail.com,fahrizi@fe.saburai.ac.id,iwan.zulfikar@fe.saburai.ac.id
}

\begin{abstract}
Abstrak. Salah satu tugas pemerintah yang juga sekaligus hak dari warga adalah terselenggaranya pelayanan publik, perizinan merupakan wujud pelayanan publik yang sangat menonjol dalam tata pemerintahan. Objek penelitian ini adalah pegawai di Dinas Kependudukan Dan Pencatatan Sipil Kabupaten Pesisir Barat, yang beralamat di Jalan Jaya Wijaya Pekon Kampung Jawa Kecamatan Pesisir Tengah. Adapun tujuan dari penelitian ini adalah Untuk mengetahui pengaruh Budaya Kerja Terhadap Produktivitas Kerja pada Dinas Kependudukan Dan Catatan Sipil Kabupaten Pesisir Barat. Pengumpulan data penelitian menggunakan teknik populasi penelitian dari 32 responden. Hipotesis yang di ajukan adalah ".Pengaruh Budaya Kerja Terhadap Produktivitas Kerja pada Dinas Kependudukan Dan Catatan Sipil Kabupaten Pesisir Barat”.Metode penelitian yang digunakan adalah analisis kuantitatif yaitu regresi linier sederhana.Dari hasil tabel dapat diketahui bahwa tingkat signifikansi sebesar $0.00<0.05$ dengan nilai $\mathrm{t}_{\text {hitung }}>\mathrm{t}_{\text {tabel }}$ yaitu $6.399>2.039$, dengan demikian hipotesis diterima yang berarti budaya kerja berpengaruh terhadap produktivitas kerja pegawai pada Dinas Kependudukan dan Catatan Sipil Kabupaten Pesisir Barat.
\end{abstract}

Kata kunci : Produktivitas,Pegawai,Kinerja.

\section{PENDAHULUAN}

Pembangunan dan penduduk adalah dua hal yang memiliki hubungan keterkaitan integrative sehingga tidak dapat dipisahkan. Pembangunan adalah upaya sadar dan sistematis untuk mensejaterakan penduduk dalam suatu entitas negara dengan berbagai upaya dan tindakan. Penduduk adalah warga negara yang berdomisili di Kabupaten Pesisir Barat sesuai kepemilikan bukti dirinya. Dalam pembangunan berkelanjutan, penduduk tidak hanya menjadi Objek (sasaran) pembangunan tetapi juga menjadi subjek pembangunan sekaligus dapat merasakan serta menikmati hasil dari pembangunan.

Pembangunan kependudukan memiliki peran yang sangat penting dalam pencapaian tujuan pembangunan, terutama dalam peningkatan kualitas sumber daya manusia. Pembangunan kependudukan bertujuan untuk melakukan pengendalian kuantitas penduduk sebagai salah satu aspek penting yang harus dilakukan guna menjamin tercapainya pertumbuhan penduduk yang seimbang. Jumlah penduduk yang besar dengan pertumbuhan cepat, kualitas rendah, persebaran tidak merata akan menghambat tercapainya kondisi ideal antara kualitas, kuantitas mobilitas, dan daya dukung lingkungan. Pembangunan harus dilakukan oleh penduduk dan untuk penduduk, oleh karena itu perencanaan pembangunan harus didasarkan pada kondisi penduduk

Perkembangan Kependudukan dan pembangunan dapat berhasil jika pengelolaan dan penyajian Data kependudukan bersekala Nasional atau Daerah dapat berjalan dengan baik. Data kependudukan yang diolah dengan baik dan sistematis akan menjadi informasi yang 
berguna untuk menunjang pembangunan kependudukan.

Salah satu tugas pemerintah yang juga sekaligus hak dari warga adalah terselenggaranya pelayanan publik, perizinan merupakan wujud pelayanan publik yang sangat menonjol dalam tata pemerintahan.Dalam relasi antara pemerintah dan warganya seringkali pelayanan menjadi indikator untuk menilai apakah suatu pemerintah sudah mencapai kondisi "Good Government governance" atau belum. Birokrasi pelayanan merupakan salah satu permasalahan yang menjadi kendala Masyarakat dan kalangan dunia usaha sering mengeluhkan proses pelayanan oleh pemerintah yang tidak memiliki kejelasan prosedur, berbelit-belit, tidak transparan, waktu pemrosesan yang tidak pasti dan tingginya

Dalam upaya meningkatkan mutu pelayanan kepada masyarakat, pada tahun 2019 Dinas Disdukcapil Kabupaten Pesisr Barat sepakat telah mengambil suatu kebijakan membentuk Unit Pelayanan. Unit tersebut untuk menciptakan iklim yang mendorong kearah terciptanya keseragaman pola dan langkah penyelenggaraan dan pelayanan oleh aparatur pemerintah kepada masyarakat dan agar adanya keterpaduan yang terkoordinasi dalam proses pemberian perizinan maupun non perizinan. Berikut disampikan data pegawai, jumlah jam kerja pada Dinas Kependudukan Dan Catatan Sipil Kabupaten Pesisir Barat tahun 2018.

Budaya kerja pada Disdukcapil Kabupaten Pesisir Barat berada pada kategori masih kurang maksimal. Sikap profesionalime, etika, semangat pengabdian dan motivasi kerja berada pada kategori cukup baik. Namun dalam hal komitmen terhadap tugas pelayanan masih belum optimal. Selain aspek budaya kerja, aspek lain yang memiliki peranan penting dapat berpengaruh terhadap kinerja karyawan adalah aspek komitmen organisasional. Komitmen organisasional dapat terbentuk karena adanya beberapa faktor, baik dari organisasi, maupun dari individu sendiri. Dalam perkembangannya affective commitment, continuance commitment, dan normative commitment, masing- masing memiliki pola perkembangan tersendiri (Allen \& Meyer, 2015). Menurut Bateman \& Strasser; Morris \& Steers (dalam Luthan; 2010) organisasi yang mempengaruhi perkembangan affective commitment adalah sistem desentralisasi. Komitmen yang baik didalamnya dimana komitmen yang tinggi akan mendorong pegawai untuk memberikan tenaga dan pikirannya secara maksimal pada suatu organisasi.

Berdasarkan uraian latar belakang diatas, penulis tertarik untuk melakukan penelitian yang berjudul: ".Pengaruh Budaya Kerja Terhadap Produktivitas Kerja pada Dinas Kependudukan Dan Catatan Sipil Kabupaten Pesisir Barat".

\section{KAJIAN TEORI}

\section{Deskripsi Budaya Kerja}

Budaya berasal dari bahasa Sansakerta "budhayah" sebagai bentuk jamak dari kata dasar "budhi" yang artinya akal atau segala sesuatu yang berkaitan dengan akal pikiran, nilai-nilai dan sikap mental (Kep Menpan No.25/KEP/M.PAN/04/2012). Budaya berarti memberdayakan budi sebagaimana dalam bahasa Inggris di kenal sebagai culture (latin - cotere) yang semula artinya mengolah atau mengerjakan sesuatu (mengolah tanah pertanian), kemudian berkembang sebagai cara manusia mengaktualisasikan nilai (value), karsa (creativity), dan hasil karyanya (performance). Budidaya dapat juga diartikan sebagai keseluruhan usaha rohani dan materi termasuk potensi-potensi maupun keterampilan masyarakat atau 
kelompok manusia. Budaya selalu bersifat sosial dalam arti penerusan tradisi sekelompok manusia yang dari segi materialnya dialihkan secara historis dan diserap oleh generasi-generasi menurut "nilai" yang berlaku. Nilai disini adalah ukuran-ukuran yang tertinggi bagi perilaku manusia.

Dalam West (2010:128)

mendefinisikan budaya sebagai asumsiasumsi dan pola-pola makna yang mendasar, yang dianggap sudah selayaknya dianut dan dimanifestasikan oleh semua fihak yang berpartisipasi dalam organisasi. Budaya diartikan juga sebagai seperangkat perilaku, perasaan dan kerangka psikologis yang terinternalisasi sangat mendalam dan dimiliki bersama oleh anggota organisasi (Osborn dan Plastrik, 2010: 252). Sehingga untuk merubah sebuah budaya harus pula merubah paradigma orang yang telah melekat. Pada bagian lain Sofo (2013: 384) memandang budaya sebagai sesuatu yang mengacu pada nilainilai, keyakinan, praktek, ritual dan kebiasaan-kebiasaan dari sebuah organisasi. Dan membantu membentuk perilaku dan menyesuaikan persepsi

$$
\text { Pentingnya budaya dalam }
$$

mendukung keberhasilan satuan kerja menurut Newstrom dan Davis (2013: 5859); budaya memberikan identitas pegawainya, budaya juga sebagai sumber stabilitas serta kontinyuitas organisasi yang memberikan rasa aman bagi pegawainya, dan yang lebih penting adalah budaya membantu merangsang pegawai untuk antusias akan tugasnya. Sedangkan tujuan fundamental budaya adalah untuk membangun sumber daya manusia seutuhnya agar setiap orang sadar bahwa mereka berada dalam suatu hubungan sifat peran sebagai pelanggan pemasok dalam komunikasi dengan orang lain secara efektif dan efisien serta menggembirakan (Triguno, 2014:6)

\section{Pengertian Produktivitas Kerja}

Produktivitas adalah perbandingan antara hasil yang didapat dengan sumber daya yang diperlukan". (Payaman J. Simanjuntak, 2010 : 16) Pengertian produktivitas menurut J. Ravianto sebagai berikut :

"Produktivitas mengandung pengertian sikap mental yang selalu mempunyai pandangan bahwa mutu kehidupan hari ini harus lebih baik dari hari kemarin dan hari esok lebih baik dari hari ini. Secara umum produktivitas mengandung pengertian perbandingan antara hasil yang dicapai dengan keseluruhan sumber daya yang dipergunakan". (J. Ravianto, 2011 : 46)

Produktivitas adalah kemampuan seperangkat sumber-sumber ekonomi untuk menghasilkan sesuatu atau diartikan juga sebagai perbandingan antara pengorbanan (input) dengan penghasilan (output). (John Soeprihanto, 2012 : 36) Dari pendapat tersebut dapat disimpulkan bahwa produktivitas adalah perbandingan antara hasil yang didapat dengan sumber daya yang dipergunakan.

\section{Faktor-faktor yang mempengaruhi produktivitas}

"Produktivitas tenaga kerja dipengaruhi oleh berbagai faktor yang berhubungan dengan tenaga kerja itu sendiri maupun yang berhubungan dengan lingkungan perusahaan dan kebijaksanaan pemerintah secara keseluruhan, seperti pendidikan, keterampilan, disiplin, sikap dan etika kerja, motivasi, gizi dan kesehatan, tingkat penghasilan, jaminan sosial, lingkungan dan iklim kerja, hubungan industrial dan kebijaksanaan pemerintah tentang produksi, investasi, perizinan, teknologi, fiskal, harga, distribusi dan lain-lain". (Payaman J. Simanjuntak, $2010: 13$ )

Sedangkan menurut pendapat J. Ravianto yaitu : 
a. Latar belakang pendidikan dan latihan

b. Alat-alat produktivitas yang digunakan dan teknologi dalam proses produksi.

c. Sistem nilai, nilai-nilai sosial masyarakat atau juga faktor lingkungan hidup tenaga kerja.

d. Lingkungan pekerjaan atau iklim kerja

e. Derajat kesehatan (kesehatan lingkungan), nilai gizi makanan, saitasi, tersedianya air bresih.

f. Tingkat upah yang berlaku

(J. Ravianto, 2011 : 101)

"Faktor-faktor yang dapat mempengaruhi tingkat produktivitas teanga kerja antara lain pendidikan dan latihan keterampilan, gizi / nutrisi dan kesehatan, bakat atau bawaan, motivasi/kemauan, keterampilan kerja, kesempatan manajemen dan kebijakan pemerintah". (John Suprihanto, 2012 : 73)

Faktor-faktor tersebut dapat mempengaruhi produktivitas baik secara langsung tidak langsung. Produktivitas tenaga kerja dipengaruhi pula tingkat kehadiran karyawan dalam tempat kerja dipengaruhi pula tingkat kehadiran karyawan dalam tempat kerja atau absensi karyawan. Produktivitas tidak mungkin tercapai secara optimal jika tingkat kehadiran karyawan sangat rendah, karena karyawan tidak masuk kerja, secara optimal tidak akan menghasbiskan produk / jasa seperti yang diharapkan.

Dari uraian diatas disimpulkan bahwa agar produktivitas tenaga, kerja dapat ditingkatkan maka hal-hal yang harus diperhatikan :

a. Kualitas dan kemampuan fisik tenaga kerja.

b. Sarana pendukung, yang meliputi antara lain :

1) Kerja antara lingkungan lain berupa sarana, peralatan produksi, teknologi dan keadaan lingkungan kerja.

2) Pemenuhan dan kesejahteraan dan kebutuhan tenaga kerja antara lain berupa jaminan sosial, tunjangan sistem pengupahan, pemberian invensive yang tepat dan pemenuhan kebutuhan-kebutuhan yang lain.

3) kemampaun manajemen dalam menggunakan sumber-sumber daya yang ada secara maksimal dan menciptakan sistem kerja yang baik.

\section{METODE PENELITIAN}

\section{Objek Penelitian}

Objek penelitian ini adalah pegawai di Dinas Kependudukan Dan Pencatatan Sipil Kabupaten Pesisir Barat, yang beralamat di Jalan Jaya Wijaya Pekon Kampung Jawa Kecamatan Pesisir Tengah Penelitian ini di laksanakan dari bulan April sampai dengan Juli 2019.

\section{Metode dan Teknik Pengumpulan Data}

Dalam penelitian ini jenis data yang diperlakukan adalah :

a. Data primer yaitu jenis data yang dikumpulkan dan diolah langsung dari objek penelitian yaitu dari Dinas Kependudukan Dan Catatan Sipil Kabupaten Pesisr Barat, seperti catatan, agenda, dokumen dan lain-lain.

b. Data Sekunder yaitu data yang bersumber dari luar objek penelitian seperti buku-buku, majalah, yang berkaitan dengan masalah penelitian ini.

Langkah-langkah pengumpulan data yang penulis lakukan dengan mengadakan penelitian lapangan, adapun teknik yang digunakan dalam pengumpulan data adalah dengan :

1. Observasi, yaitumengadakan survey atau pengamatan langsung kelokasi penelitian. 
2. Interview atau wawancara, yaitu mengadakan tanya jawab langsung dengan pegawai.

3. Dokumentasi, yaitu mengumpulkan dan mencatat dokumentasi yang relevan.

4. Quisioner, yaitu membuat pertanyaan yang berhubungan dengan varibael penelitian.

\section{Sampel dan Populasi}

Sampel adalah sebagian dari jumlah anggota populasi Dalam penelitian survei ini teknik pengambilan sampel sangat penting, sehingga sedapat mungkin sampel mewakili populasi yang diteliti dan pengambilan sampel yang baik akan mempengaruhi validitas hasil penelitian. (Notoatmodjo, 2010:45). Dalam penelitian ini, penelitian menggunakan data populasi artinya seluruh pegawai di Dinas Kependudukan Dan Catatan Sipil Kabupaten Pesisir Barat. Adapun jumlah seluruh populasi pegawai di Dinas Kependudukan Dan Catatan Sipil Kabupaten Lampung Barat yang berjumlah 32 orang pegawai.

\section{Metode Analisis Data}

Metode analisis yang digunakan dalam penelitian ini adalah metode analisis kuantitatif, yaitu metode yang dilakukan untuk menganalisis data dengan menggunakan penalaran dan penelaahan dengan berpedoman pada pendekatan teoritis. Kalaupun ada data berupa angkaangka sifat analisisnya hanya terbatas pada pemberian informasi, menilai atau mengevaluasi data angka tersebut kemudian melakukan penafsiran dan menyimpulkan.

Analisis Regresi Linier Sederhana digunakan untuk meramalkan besarnya pengaruh variabel bebas terhadap variabel terikat. Dengan kata lain analisis ini digunakan untuk mengetahui besarnya pengaruh produktivitas kerja (variabel terikat) bila kualitas budaya kerja (variabel bebas) berubah. Model matematisnya adalah sebagai berikut:

$$
Y=a+b X
$$

Keterangan :

$\mathrm{Y}=$ Produktivitas Kerja

$\mathrm{X}=$ Budaya kerja

$\mathrm{a}=$ Konstanta sisipan

$\mathrm{b}=$ Koefisien regresi yang dihubungkan dengan variabel bebas.

Uji hipotesis yang digunakan adalah Uji $\mathrm{t}$ yaitu untuk menguji signifikasi konstanta dari setiap variabel independen. Dengan rumus sebagai berikut (Sugiyono, 2011;78) :

$$
t=r \sqrt{\begin{array}{c}
N-2 \\
\left(1-r^{2}\right)
\end{array}}
$$

$\mathrm{r} \quad=$ Korelasi parsial yang ditemukan. $\mathrm{n}$ = Jumlah sampel.

$\mathrm{t}=\mathrm{t}_{\text {hitung }}$ yang selanjutnya dibandingkan dengan $t_{\text {tabel. }}$.

\section{HASIL DAN PEMBAHASAN}

\section{Pengujian Regresi Sederhana}

Dari pengolahan data statistik maka diperoleh persamaan regresi linier sederhana sebagai berikut :

Tabel Hasil Uji Regresi Sederhana

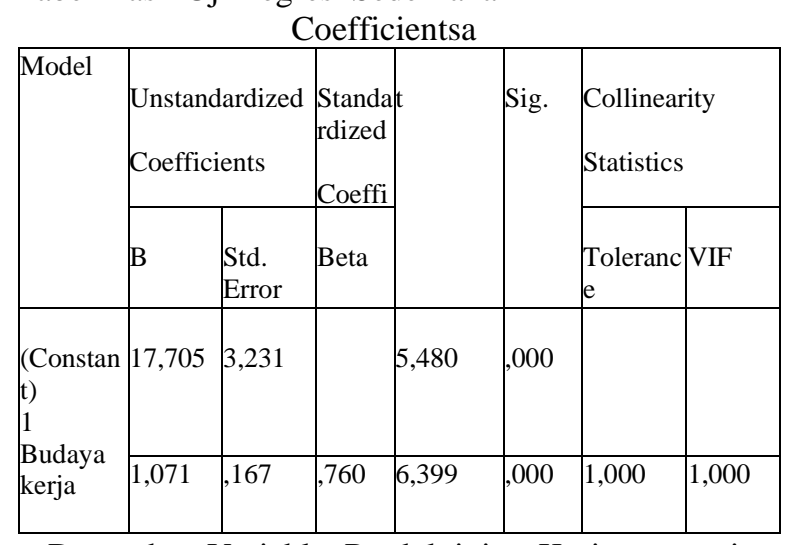

a. Dependent Variable: Produktivitas Kerja pegawai Sumber: Data primer yang telah diolah, 2019 
Berdasarkan tabel diatas dapat dilihat persamaan regresi linier sederhana sebagai berikut:

1. Konstanta $(\alpha)$

Nilai konstanta yang diperoleh sebesar 17.705, hal ini berarti bahwa jika variabel independen (budaya kerja) adalah bernilai nol, maka besarnya Produktivitas kerja pegawai yang terjadi adalah 17.705.

2. Koefisien regresi $(\beta) X$

Nilai koefisien regresi variabel budaya kerja $(\mathrm{X})$ sebesar 1.071, hal ini menunjukkan bahwa setiap kenaikan satu satuan Budaya kerja akan mengakibatkan Produktivitas kerja pegawai sebesar 1.071.

\section{Uji Koefisien Determinan $\left(\mathbf{R}^{2}\right)$}

- Koefisien determinan digunakan untuk mengetahui kontribusi variabel bebas dalam menjelaskan variabel terikat. Semakin besar nilai koefisien determinasi maka menunjukkan semakin besar pula pengaruh variabel terikat terhadap variabel bebas. Berikut adalah hasil perhitungan nilai R2 dan koefisien determinasi dalam penelitian ini :

Tabel Hasil Uji Koefisien Determinasi Model Summaryb

\begin{tabular}{|l|l|l|l|l|l|}
\hline Model & $R$ & R Square & $\begin{array}{l}\text { Adjusted R } \\
\text { Square }\end{array}$ & $\begin{array}{l}\text { Std. Error of Durbin- } \\
\text { the } \\
\text { Estimate }\end{array}$ & Watson \\
\hline 1 &, $760 a$ &, 577 &, 563 & 1,47747 & 1,373 \\
\hline
\end{tabular}

a. Predictors: (Constant), Budaya kerja

b. Dependent Variable: Produktivitas Kerja pegawai Sumber: Data primer yang telah diolah, 2019

Hasil pengujian di atas menunjukkan bahwa nilai $R$ square sebesar 0.577 Nilai $R$ square ini menunjukkan bahwa besarnya kontribusi variabel independen.

\section{Uji Hipotesis (Uji Statistik t)}

Pengujian ini dilakukan untuk menjawab model kelayakan hipotesis penelitian. Pengujian dilakukan dengan menggunakan uji t pada tingkat kepercayaan 95\% atau $\alpha$ sebesar 0.05 dari hasil output SPSS yang diperoleh apabila $t_{\text {hitung }}>t_{\text {tabel. }}$. Maka model dinyatakan layak digunakan dalam penelitian ini dan sebaliknya apabila $t_{\text {hitung }}<t_{\text {tabel }}$, maka model dikatakan tidak layak, atau dengan signifikan (Sig) $<0.05$ maka model dinyatakan layak digunakan dalam penelitian ini dan sebaliknya apabila signifikan (Sig) > 0.05 maka model dinyatakan tidak layak digunakan.

Tabel Hasil Uji Hipotes

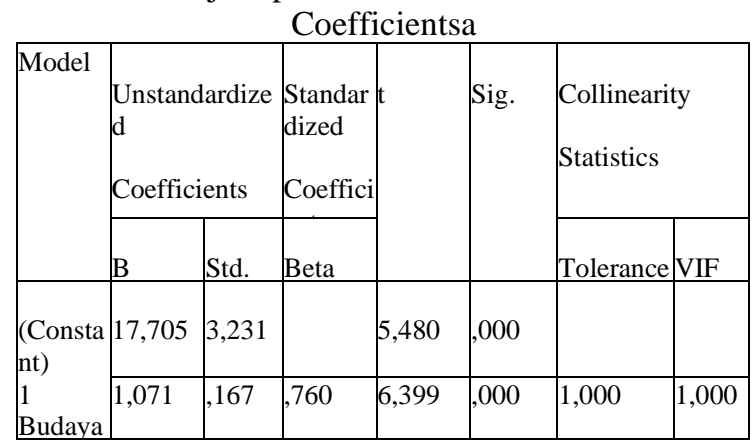

a. Dependent Variable: Produktivitas Kerja pegawai Sumber: Data primer yang telah diolah, 2019

Pengujian pada tabel dapat menjawab hipotesis yang menyatakan "budaya kerja berpengaruh terhadap Produktivitas kerja pegawai." Pengujian dilakukan dengan menggunakan uji t yang menunjukkan bahwa budaya kerja berpengaruh terhadap produktivitas kerja pegawai. Pengujian dilakukan dengan menggunakan uji t pada tingkat keyakinan signifikansi $\alpha 0.05$. Dari hasil tabel dapat diketahui bahwa tingkat signifikansi sebesar $0.00<0.05$ dengan nilai $t_{\text {hitung }}>t_{\text {tabel }}$ yaitu $6.399>2.039$, dengan demikian hipotesis diterima yang berarti budaya kerja berpengaruh terhadap produktivitas kerja pegawai pada Dinas Kependudukan dan Catatan Sipil Kabupaten Pesisir Barat.

\section{KESIMPULAN DAN SARAN}

\section{Kesimpulan}


Berdasarkan hasil penelitian dan pembahasan yang sudah dilakukan, maka hal yang dapat disimpulkan bahwa:

Hasil pengujian di atas menunjukkan bahwa nilai $\mathrm{R}$ square sebesar 0.577

Nilai $\mathrm{R}$ square ini menunjukkan bahwa besarnya kontribusi variabel independen terhadap variabel dependen adalah sebesar $57,7 \%$, sedangkan sisanya sebesar $42,3 \%$ ditentukan oleh variabel lain yang tidak teridentifikasi dalam penelitian ini. Nilai signifikansi sebesar 0.00 lebih kecil dari 0.05. Dengan melihat tingkat signifikansi tersebut, maka model ini dapat digunakan untuk Produktivitas kerja pegawai (Y), dengan demikian persamaan model ini bersifat fit atau layak digunakan. Pengujian menjawab hipotesis yang menyatakan "Budaya kerja berpengaruh terhadap Produktivitas kerja pegawai." Pengujian menggunakan uji $t$ yang menunjukkan bahwa Budaya kerja berpengaruh terhadap Produktivitas kerja pegawai. Pengujian dilakukan dengan menggunakan uji t pada tingkat keyakinan signifikansi $\alpha 0.05$. Dari hasil tabel 4.7 dapat diketahui bahwa tingkat signifikansi sebesar $0.00<0.05$ dengan nilai $t_{\text {hitung }}>t_{\text {tabel }}$ yaitu $6.399>2.039$, dengan demikian hipotesis diterima yang berarti Budaya kerja berpengaruh terhadap Produktivitas kerja pegawai pada Dinas Kependudukan dan Pencatatan Sipil Kabupaten Pesisir Barat.

\section{Saran}

Adapun saran dari penelitian ini adalah sebagai berikut :

1. Dilakukannya pendalaman tentang deskripsi kerja di seksi atau bidang masing masing sehingga adanya pegawai yang tidak menguasai deskripsi dapat terhindarkan. Langkah pendalamandapat dilakukan dengan sosialisasi antar bidang, dilakukannya koordinasi antar bidang secara rutin sehingga terhindari tumpang tindih tupoksi.
2. Dilakukannya kegiatan pengembangan sumber daya manusia berupa pendidikan dan latihan serta mendorong pegawai yang ada untuk meningkatkan pendidikan dan keahliannya dengan melalui pendidikan formal, dorongan dapat dilakukan melalui beasiswa atau kerjasama antar BPS dan perguruan tinggi sehingga dengan langkah pengembangan SDM ini para pegawai dapat menguasai tugas yang diberikan dikarenakan kemampuan individu pegawai tersebut dapat berkembang.

3. Diberikannya motivasi kepada pegawai berupa penghargaan atau insentif kepada pegawai yang mampu mencapai target kerja dan tepat waktu penyelesaian, sehingga para pegawai dapat terpacu untuk mencapai target kerja yang ditugaskan kepadanya.

\section{DAFTAR PUSTAKA}

Allen dan Meyer ; 2015 Allen, Harrelt and Meyer. Policy Science and Future Research. New York: Praeger Plubisher.

Arikunto,Suharsimi 2010. Metode Penelitian. Jakarta: BP FE UI.

Algifari, 2013. Statistik Dskriptif. Jakarta: Elex Media Kompetindo

Gering Supriyadi, dan Tri Guno. 2017. Evaluasi Kinerja Sumber Daya Manusia. Bandung: PT. Refika Aditema

Hasibuan, 2010. Perilaku Organisasi, Jakarta: Salemba Empat

J.Supranto. 2012. Metode Penelitian Diskriftif. Jakarta: ANDI Offset.

Kisdarto Atmosoeprapto ;2010; Perilaku 
Organisasi, Jakarta, Salemba Empat

Luthans .2010; Luthans, Fred,.

Organizational Behavior, 7-ed. Mc.

Graw-Hill Interntional, New York

Newstrom dan Davis ;2013;

Organizational Behavior, New Jersey: Pearson Prentice Hall.

Osborn dan Plastrik,2010: Organizational

Behaviour, Edisi Kesepuluh,

Penterjemah Drs. Benyamin

Molan, PT. INDEKS Kelompok

GRAMEDIA

Payaman J. Simanjuntak, 2010

Kepemimpinan dan Perilaku

Organisasi. (Edisi ke-3), Jakarta:

PT. rajaGrafindo Persada, 2013

M.Sinungan, 2009. Manajemen Sumber

Daya Manusia.Jakarta: Penerbit

Yayasan Gunung Agung.

Soeratno (dalam Purnamasari). 2008. Psikologi Islami: Seri Sumber

Daya Manusia.Yogjakarta: Liberty.

Sugiyono, 2010. Metode Penelitian Bisnis.

Cetakan $\mathrm{Ke}-\mathrm{15}$. Bandung:

CV.Alfabeta. 